\title{
Volatility Spillover Analysis Post Implementation of AEC 2015 Agreement: Empirical Study on ASEAN-5 Stock Market
}

\author{
Yunia Panjaitan ${ }^{1} \&$ Siti Saadah ${ }^{1}$ \\ ${ }^{1}$ Faculty of Economics and Business, Atma Jaya Catholic University, Jakarta, Indonesia \\ Correspondence: Siti Saadah, Faculty of Economics and Business, Atma Jaya Catholic University, Jl. Jend, \\ Sudirman Kav 51, Jakarta Selatan 12930, Indonesia. Tel: 62-815-1122-3365.
}

Received: January 18, 2018

Accepted: February 7, 2018

Online Published: March 13, 2018

doi:10.5430/ijfr.v9n2p105

URL: https://doi.org/10.5430/ijfr.v9n2p105

\begin{abstract}
Efforts to improve financial integration that continue to be implemented after the implementation of the Asean Economic Community 2015 agreement, can encourage increased integration of capital markets in countries within the region. This study was conducted to investigate the spillover of volatility between stock markets that accompanied the ongoing efforts of financial integration carried out by ASEAN member countries. Investigation of volatility spillover is done by applying Exponential GARCH method on time series daily data of stock return of ASEAN-5 countries period September 2016 - December 20, 2017. If previous studies found significant spillover of volatility from Singapore, Malaysia, Thailand and Philippines, the results of this study show that only Singapore's stock exchanges consistently have a significant impact on the Indonesian stock market. The turmoil in the Singapore stock market will be consistently transmitted to the Indonesian stock market. However, efforts to improve the financial integration carried out by ASEAN member countries have not consistently caused the turmoil in Malaysia, Thailand and the Philippines stock exchange to be transmitted to the Indonesian stock market.
\end{abstract}

Keywords: ASEAN economic community, financial integration, volatility spillover, EGARCH

\section{Introduction}

In the implementation of the process of economic integration, at the end of November 2015, the leaders of ASEAN countries signed a new document "ASEAN 2025: Forging Ahead Together" whose contents are the targets to be achieved by ASEAN in the next 10 years to realize the integration of the ASEAN region more tight and open. This target marks a new round of liberalization negotiations among ASEAN members, including the goal of ASEAN financial services liberalization. ASEAN cooperation forum on the financial path, in 2016 has also established Strategic Action Plan (SAP) for Financial Integration 2025 and compiled the Key Performance Indicators (KPI) as an evaluation tool for achieving the financial integration process. The KPI is structured into three pillars, namely financial integration, financial inclusion, and financial stability. The ASEAN cooperation forum on the financial path continues to monitor implementation and the risks that may hamper the process of financial integration.

Some ASEAN Working Committees are the committee for capital flows liberalization, the committee for financial services liberalization, and the committee for banking integration frameworks continue to work to facilitate the need for capacity building of each member in achieving ASEAN financial integration. The financial services liberalization committee continues the integration of the financial sector through discussions of the draft of financial sector cooperation within the framework of the ASEAN Framework Agreement on Services.

The liberalization of financial services in the concept of ASEAN Economic Community 2025 is achieved through the alignment of three main areas, including capital account liberalization. This liberalization of capital flows is expected to realize greater capital traffic intra ASEAN countries. However, the liberalization of capital flows, particularly in terms of portfolio investments including short-term investment instruments, has the potential to create systemic risks that can disrupt the stability of the financial system. If the level of economic and financial development of countries in this region is different, this financial liberalization may lead to the phenomenon of hot money from more developed countries to countries whose economies are in under-developed condition. In the case of ASEAN, hot money may occur from ASEAN-5 countries to other countries within the region but outside ASEAN-5, or may occur from Singapore to countries within the region included in ASEAN-5. The occurrence of capital reversal phenomenon from hot money or the phenomenon of contagion effect is an incident that must be 
monitored by the financial authorities in Indonesia due to the emergence of potential systemic risks that can threaten the stability of the Indonesian economy.

To monitor the risk of inhibiting the process of financial integration, one of the agencies in ASEAN continues to calculate some KPI's, one of which is the pillar of financial integration. In the midst of continuous efforts to realize the financial integration of ASEAN countries, this study aims to examine the spillover of volatility among the stock markets of the countries included in the ASEAN-5. The study of volatility spillovers is becoming more attractive in the era of financial integration because many empirical studies show that the development of financial market integration causes the movement of key stock market indicators in a country to easily and quickly be transmitted to stock markets in other countries. Financial liberalization allows a business entity in one State to sell securities or financial instruments in another State as a source of financing for its business expansion. Under these conditions financial market integration will be created. Integration of capital markets between countries will lead to correlation of return and volatility between markets. This integration resulted in financial markets in a country becoming more vulnerable to shocks occurring in financial markets of other States.

During the year 2017 there has been an increase in stock prices that began with the rise of stock indexes in developed countries followed by an increase in stock index of developing countries (Bank Indonesia, 2017). This suggests a global economic recovery that fosters investor optimism to invest in stocks, risky assets, which promise higher returns. The report of Bank Indonesia said that in the third quarter of 2017, the ASEAN economy also entered the momentum of strengthening where the growth rate of each country recorded an increase compared with the previous quarter. The dynamics of rising stock indices in the ASEAN market are expected to follow the global economic upturn, but it is important to recognize that there are financial risks that lurk investment in the stock market. This global economic recovery contributes significantly to ASEAN member countries, such as creating an investment climate that attracts portfolio investment managers. This can be observed from the Indonesian stock market, as one of the ASEAN members, the rise of the Composite Stock Price Index (IHSG) which reached 5,900.85 in the third quarter of 2017, which increased by $1.22 \%$ compared to the position in the previous quarter and IHSG managed to rank tenth after Japan (OJK, 2017).

The liberalization and deregulation of financial markets conducted by ASEAN member countries is aimed at making the movement of capital flows from one country to another more efficient. Along with the development of communication and information media, financial markets in the ASEAN region are increasingly more integrated with global market. This has a positive impact on trade relations and financial relations among ASEAN countries, certainly for the Indonesian economy. But on the other hand, the businessmen and investors need to be aware of the possibility of transmission of shocks from other countries to Indonesia. This inter-economic interdependence can be reflected in the correlation between stock markets that makes each market more vulnerable to shocks and crises, due to contagion. The normal interdependence between markets in an economy becomes the transmission channel of shocks that occur both locally and globally. Dornbusch (2000) defines Volatility spillover (contagion) as the spread of inter-market disruption in one country to another which can be observed through stock price index, exchange rate, and capital flows. Basically spillover can be caused by several factors namely reduced competitiveness, decreased commodity prices, and liquidity losses (Rijckeghem and Weder, 1999). The most prominent and most common spillover is through bilateral trade between countries where the two countries are competing in the same market (third market). However, spillover may also occur due to financial market linkages, especially through bank lending, where losses in one State bring a bank to sell its assets residing in another State in order to maintain its capital adequacy ratio. This is called cross-border spillover.

Excessive volatility spillover may increase financial risk and decrease international diversification opportunities especially for Indonesia as one of the developing countries within ASEAN region. Although according to Yarovaya (2015), financial markets in the Asian region are characterized by lower levels of spillovers compared to European and American markets. The most powerful spillovers levels in the Asian market region come from the UK mainly on HongKong, Japan and Singapore markets. The three markets of this country are also affected by shocks coming from markets in the Americas. This explains the fact that the three markets are becoming more integrated with the world economy compared to other emerging markets in the same region. Unlike Abou-Zaid's (2011) opinion that the stock market in developing countries is typically characterized by high volatility rates, where spillover returns go from US to Egypt and Israel, but not to Turkey. While the UK market has no effect at all to the 3 emerging markets. These findings have important implications, particularly for the establishment of investor portfolios and trading decisions. This study is reinforced by Badhani (2009) where his empirical studies show that volatility in the US stock market has a significant impact on the dynamics of stock market volatility in developing countries including India. This study observed a significant association of asymmetry. Return The Indian stock market is more sensitive to negative 
shocks in the US market than positive shocks. Positive shocks in the US market do not affect the volatility in the Indian stock market, but negative shocks significantly increase volatility. Beirne, et al (2009) also concluded that the volatility spillover occurs dynamically from the developed Country to the majority of emerging markets and there is an increase in turbulent times compared to non-turbulent times. Research on volatility spillover in ASEAN stocks market has been done by Sok-Gee and Karim (2010) which concludes that the share of stock return in ASEAN is highly dependent on their past return and more influenced by American market compared to Japanese market. In addition, it was found that the movement of share price in ASEAN-5 occurred through intraregional relationship.

In contrast to previous studies, using daily return data from 2016 to December 2017 the volatility spillover modeling in this study was conducted with the aim of comparing ASEAN-4 countries where the spillover intensity most significantly impacted the volatility of Indonesian capital market returns. This information is important to the financial authorities in order for the shocks that occur in the external market to be anticipated so as not to affect the systemic and disrupt the stability of the domestic economy.

\section{Method}

Since the implementation of the economic cooperation agreement between ASEAN countries in 2015, efforts to promote the improvement of financial integration continue to be undertaken by ASEAN member countries. This study was conducted to investigate the spillover of volatility between stock markets that accompanies the financial integration efforts that have been done.

The study on volatility spillover in this study will be conducted using daily time series data across all capital markets of ASEAN countries 5 within the period September 2016 to December 20, 2017, by applying the EGARCH model. The use of this method, as stated by Hill, Griffiths, and Lim, (2012), in the stock market, when negative news enters the market, asset prices will tend to enter a turbulent phase and volatility increases, but if positive news goes into the market, volatility tends decreased and the market entered in the tranquil phase.

The EGARCH specifications were applied in this study:

$$
\begin{gathered}
y_{t}=\mu+u_{t} \quad u_{t} \approx N\left(0, \sigma_{t}^{2}\right) \\
\ln \left(\sigma_{t}^{2}\right)=\omega+\beta \ln \left(\sigma_{t-1}^{2}\right)+\gamma \frac{u_{t-1}}{\sqrt{\sigma_{t-1}^{2}}}+\alpha\left[\frac{\left|u_{t-1}\right|}{\sqrt{\sigma_{t-1}^{2}}}-\sqrt{\frac{2}{\pi}}\right]
\end{gathered}
$$

The $(\gamma+\alpha)$ and $(\gamma-\alpha)$ parameters in the above equations reflect the asymmetric response of volatility to positive and negative shocks. If $\gamma<0$ the positive return shock will increase the volatility is smaller than the negative shocks with the same magnitude. Of course, another advantage of this model is that the sign for its parameters should not be subject to non-negativity constraints as in the standard GARCH model.

Identification of inter-market spillover volatility is done by modifying equation (2). The volatility component $(\mathrm{GARCH})$ resulting from the ASEAN 4 market modeling will be incorporated into the EGARCH model for the Indonesian capital market as an explanatory variable in the conditional variance equation.

Thus, the spillover effect of the Singapore, Malaysia, Thailand, and Philippine stock markets against the Indonesian capital market can be accommodated in the following specifications:

$$
\begin{aligned}
\ln \left(\sigma_{t}^{2}\right)= & \omega+\beta \ln \left(\sigma_{t-1}^{2}\right)+\gamma \frac{u_{t-1}}{\sqrt{\sigma_{t-1}^{2}}}+\alpha\left[\frac{\left|u_{t-1}\right|}{\sqrt{\sigma_{t-1}^{2}}}-\sqrt{\frac{2}{\pi}}\right]+\delta_{1} \ln \left(\sigma_{t, S T I}^{2}\right)+\delta_{2} \ln \left(\sigma_{t, K L C I}^{2}\right) \\
& +\delta_{3} \ln \left(\sigma_{t, S E T}^{2}\right)+\delta_{4} \ln \left(\sigma_{t, P S E I}^{2}\right)
\end{aligned}
$$

$\sigma_{t, S T I}^{2}, \sigma_{t, K L C I}^{2}, \sigma_{t, S E T}^{2}, \sigma_{t, P S E I}^{2}$ are respectively the shocks (volatility) occurring in the Singapore, Malaysia, Thailand, and Philippine capital markets, and thus $\left(\delta_{1}, \delta_{2}, \delta_{3}, \delta_{4}\right)$ are the parameters that measure the volatility spillover of the Singapore, Malaysia, Thailand, the Philippines to the Indonesian capital market.

Many of the results of studies and studies in the literature show that financial time series data including univariate stock index return has leptokurtic characteristics, namely the tendency that financial asset return data have a fat-tails 
distribution with high tipping on the mean, and the volatility clustering feature that is tendency where the volatility in financial asset returns on financial markets tends to be heteroskedastic. All these feature are in contrast to the properties of the Gaussian distribution. Therefore descriptive statistics related to all the above properties, will be reviewed to complement the reasons for the use of EGARCH specification in modeling the spillover of stock return volatility in the ASEAN 5 stock market.

\section{Results}

The EGARCH model used in this study is an appropriate model for data that has time-varying volatility properties. Here is a descriptive statistic about the pattern of data distribution return Jakarta Composite Index, along with testing heteroskedastik nature.

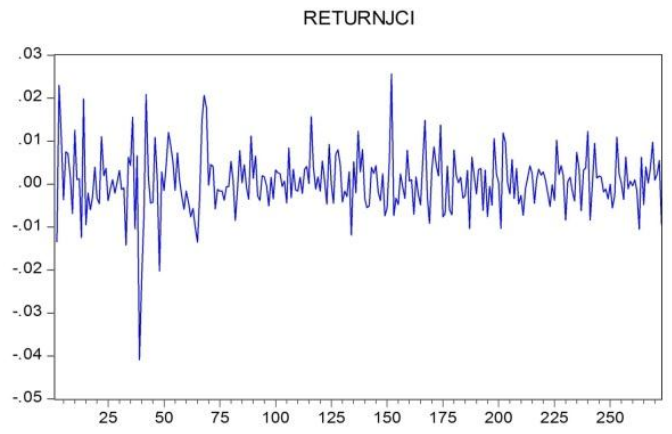

Figure 1. JCI return data

The graph above shows that the characteristics of daily return data of the Jakarta Composite Index in the period September 2016 to December 20, 2017 shows the time-volating or volatility clustering properties. There is a long enough time interval where large volatility changes are followed by subsequent big changes, and there are also periods where minor changes are followed by subsequent minor changes.
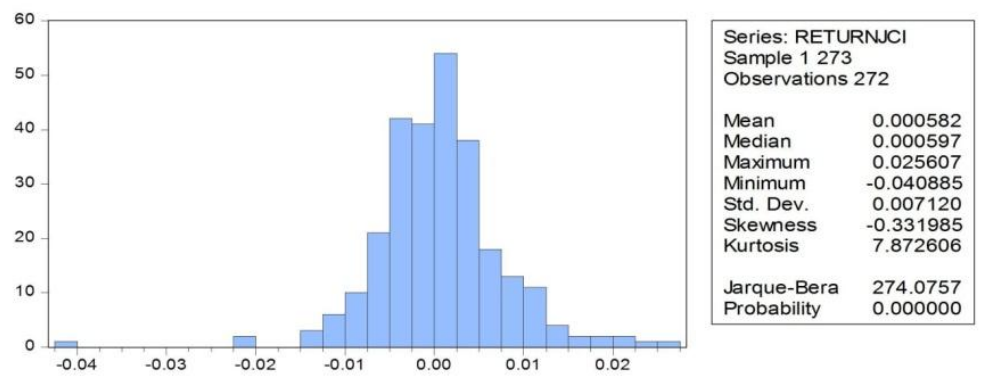

Figure 2. Distribution of return JCI data

Related to the characteristics of the data distribution pattern, as shown in Fig. 2, the magnitude of kurtosis> 3, and the statistic skewness indicates that the JCI return data show the characteristics of fat-tails and Jarque Bera normality statistic shown in the above table indicates that the JCI return data is not distributed normal. Likewise, the results of the ARCH effect test in Table 1 below show that there is an ARCH effect in the residual returnharian model of the Jakarta Composite Index (JCI). 
Table 1. Heteroskedasticity test results for JCI return data

\begin{tabular}{llll}
\hline Heteroskedasticity Test: ARCH & & \\
F-statistic & 15.38042 & Prob. F(1,269) & 0.0001 \\
Obs*R-squared & 14.65675 & Prob. Chi-Square(1) & 0.0001 \\
\hline
\end{tabular}

From various tests and observations on the characteristics of daily return data Jakarta Composite Index data can be concluded that the GARCH model specification is the right model to model JCI share return behavior that has characteristics of financial data like this.

The following is the estimation of EGARCH model to investigate the shock volatility spillover that occurred in Singapore, Malaysia, Thailand and Philippine stock exchanges against Indonesia stock market.

Table 2. Estimated EGARCH model results for Jakarta composite index returns

\begin{tabular}{llll}
\hline Mean equation & Coeffcient & z-statistic & Prob \\
\hline Constant $(\mu)$ & 0.000106 & 0.265132 & 0.7909 \\
\hline Variance equation & & & \\
\hline Constant $(\omega)$ & -1.548399 & -2.469960 & 0.0135 \\
GARCH effect $(\beta)$ & 0.888738 & 16.32239 & 0.0000 \\
Asymmetry (negative return shock) - $(\gamma)$ & -0.241994 & -2.908468 & 0.0036 \\
STI Volatility spillover $\left(\delta_{1}\right)$ & 7114.842 & 2.200131 & 0.0278 \\
KLCI Volatility spillover $\left(\delta_{2}\right)$ & 6054.704 & 1.022781 & 0.3064 \\
SET Volatility spillover $\left(\delta_{3}\right)$ & -801.9239 & -0.545745 & 0.5852 \\
PSEI Volatility spillover $\left(\delta_{4}\right)$ & 25.31700 & 0.030553 & 0.9756 \\
\hline
\end{tabular}

Table 3. Results of heteroskedastic testing for residues of the EGARCH model

\begin{tabular}{llll}
\hline Heteroskedasticity Test: & ARCH & & \\
F-statistic & 0.074816 & Prob. F(1,269) & 0.7847 \\
Obs*R-squared & 0.075352 & Prob. Chi-Square(1) & 0.7837 \\
\hline
\end{tabular}

Table 3 shows residual tests generated from EGARCH modeling for JCI return data in Table 2. Chi-Square Probits of 0.7837 shows that the residues resulting from EGARCH modeling are homoskedastic. The positive and significant parameters $\beta$ in Table 2 indicate that the impact of news on JCI's volatility return shows persistent properties throughout the analysis period. The estimation results in Table 2 also show that there is significant statistical evidence supporting the leverage effect hypothesis that bad news (negative shock) has a stronger impact on the volatility of return than good news (positive shocks). This asymmetry pattern can be seen from parameters $\gamma$ that are marked negative and significant.

The parameter $\delta_{1}$ in the model estimation results in Table 2 also shows a significant volatility spillover from the Singapore stock exchange to the Indonesian stock market. Shock / volatility return on the Singapore stock exchange will soon be transmitted to the Indonesian stock market. Other volatility spillover parameters, $\delta_{2}$, $\delta_{3}$, and $\delta_{4}$ shown in Table 2 indicate that the volatility / shock occurring in the stock exchanges of Malaysia, Thailand, and the Philippines has no significant impact on the volatility of stock returns in Indonesian stock exchanges.

\section{Discussion}

The results of this study show a significant volatility spillover from Singapore's stock exchange to the Indonesian stock market, reinforcing the same studies that have been done by some previous researchers. These findings indicate that in the area of the economy in the ASEAN region, the Indonesian stock market is consistently affected by the turmoil that occurs in the Singapore stock exchange. Not so with the Malaysian, Thailand and Philippine stock 
exchanges, efforts to improve the financial integration that has been done, have not consistently caused the turmoil in those three markets to have an impact on the Indonesian stock market.

The significance of volatility transmission from the Singapore stock exchange to the Indonesian stock exchanges shown in Table 2, in line with the results of a study conducted by Saadah (2013), and Lestano (2010). Thus the volatility transmission which is consistently observed after the efforts of financial integration until 2017 by ASEAN member countries, is the volatility transmission from the Singapore stock exchange to the Indonesian stock exchange. Singapore, which is a developed country in the ASEAN region, plays an important role as an information leader in markets in the region, and it is therefore possible that the turmoil in this country can be immediately transmitted to other markets in the region including Indonesia. Many studies conclude that significant spillover phenomena generally occur from dominant markets; capital market in developed countries to the existing market in developing countries. With the same analytical method, in the context of contemporaneous volalility spillover, the investigation related to the phenomenon of volatility spillover between Indonesia and Singapore stock market conducted by Saadah (2013), shows two important empirical findings, namely, first, that the shock / volatility of returns in exchange Singapore shares will soon be transmitted to the Indonesian stock market. This finding supports the hypothesis that emerging markets can be affected by a wave of turmoil coming from developed markets. Second, the volatility spillover occurs with an asymmetric pattern.

The study of the volatility of the Indonesian stock exchange in relation to the world's major stock exchanges will provide important information on how the impact of the stock market movements on the volatility of the Indonesian stock market. Abou-Zaid (2011) indicates that there is unidirectional volatility spillover from developed countries to emerging-market stock exchanges. These findings indicate that in the area of the economy in the ASEAN region, the Indonesian stock market is consistently affected by the turmoil that occurs in the Singapore stock exchange. Not so with the Malaysian, Thailand and Philippines stock exchanges, the efforts to improve the financial integration that has been done, have not consistently caused the turmoil in those three markets to have an impact on the Indonesian stock market.

From a macroeconomic aspect, the observation of a significant volatility spillover is closely related to the financial system stability condition. Transmission of volatility from external markets can be a source of systemic risk that can shake the stability of the financial system. The 2008 global financial crisis, initially triggered by subprime mortgage problems in the US financial sector, not only resulted in lower performance in the financial sector, but also had a negative impact on the deterioration of the Indonesian economy. The sale of financial assets in Indonesia takes place on a massive scale. History noted, at the end of August 2008, within 2 months of the JCI down from 2166 to 1256 ($42 \%)$. Similarly, other macro monetary indicators. The findings of this study, which reinforce the results of previous studies on the phenomenon of volatility spillover, should be an early warning system that shocks in external markets, especially intra-ASEAN region will be a source of systemic risk that can threaten the stability of Indonesia's financial system.

\section{References}

Abou-Zaid, \& Ahmed S. (2011, January-December). Volatility Spillover Effects in Emerging MENA Stock Markets. Review of Applied Economics, 7, 1-2.

Badhani, K. N. (2009). Response Asymmetry in Return and Volatility Spillover from the US to Indian Stock Market. The IUP Journal of Applied Finance, 15(9), 22-45.

Bank Indonesia. (2017). Perkembangan Ekonomi Keuangan dan Kerja Sama Internasional: Ekonomi Global Memasuki Siklus Pengetatan Moneter. Buletin PEKKI / Edisi IV.

Beirne, John, Guglielmo Maria Caporale, Marianne Schulze-Ghattas, \& Nicola Spagnolo. (2009, November). Volatility Spillovers and Contagion from Mature to Emerging Stock Markets, European Central Bank. Working Paper Series, No. 1113.

Dornbusch, Rudiger, Park, Yung Park, \& Stijn Claessens, Stijn. (2000). Contagion: How it spreads and How it can be stopped?. World Bank, Juli 18.

Hill, R. C., Griffiths, W. E., \& Lim, G. C. (2012). Principles pf Econometrics (4 ${ }^{\text {th }}$ ed.). Hoboken, New Jersey.

Lestano, \& Sucito, J. (2010). Spillover Volatilitas Pasar Saham Indonesia dan Singapura. Jurnal Akuntansi dan Keuangan, 12(1), 17-25.

Otoritas Jasa Keuangan (OJK). (2017). Laporan Triwulanan: Triwulan III . 
Rijckeghem, Caroline Van, \& Beatrice Weder. (1999, October). Sources of Contagion: Finance or Trade?. International Monetary Fund, Research Department.

Saadah, Siti. (2013, July). Response Asymmetry in Spillover Volatility: an Empirical Study in the Indonesia and Singapore Stock Market. Indonesian Capital Market Review, 5(2).

Sok-Gee, Chan, \& Mohd Zaini Abd Karim. (2010). Volatility Spillovers of the Major Stock Markets in ASEAN-5 with the U.S. and Japanese Stock Markets. International Research Journal of Finance and Economics, 44.

Yarovaya, Larisa, Janusz Brzeszczynski, \& Chi Keung Marco Lau. (2015). Intra- and Inter-regional Return and Volatility Spillovers Across Emerging and Developed Markets: Evidence from Stocks Indices and Stocks Index Future. International Review of Financial Analysis, 43, 96-114. https://doi.org/10.1016/j.irfa.2015.09.004 